\title{
Simultaneous detection of seven foodborne Enterobacteriaceae pathogens using multiplex PCR
}

\author{
Ahmed K.A. El-Sayed ", Mohamed I. Abou Dobara and Heba E. El-Shihy \\ Botany \& Microbiology Department, Faculty of Science, Damietta University, \\ Damietta El-Gededa, Egypt. \\ *Corresponding author: E.mail: akaelsayed@du.edu.eg
}

\begin{abstract}
Members of the family Enterobacteriaceae are major pathogens associated with gastrointestinal disorders caused by the consumption of contaminated foods. This study developed a multiplex PCR targeting specific genes for simultaneous detection and differentiation of seven major Enterobacteriaceae members, namely, Escherichia coli (uidA), Proteus sp. (atpD), Salmonella sp. (invA), Enterobacter sp. (16S rRNA), Klebsiella sp. (gyrA), Klebsiella pneumoniae (rpoB) and $K$. oxytoca (pehX) from contaminated food samples. Four main types of food samples comprise fresh, frozen, processed frozen and processed preserved samples were examined by using simultaneous amplification of those seven-targeted genes from obtained reference strains. The multiplex PCR assay showed detection sensitivity reached 5-10 cfu for each pathogen after $2 \mathrm{~h}$ of sample incubation on nutrient broth. Generally, the 7plex-PCR assay revealed that the most common pathogens found in 192 different food samples with high frequency was Salmonella which distributed within most of all types of food having the maximum occurrence frequency reached $6.77 \%$ in hotdog and sausage samples followed by $5.21 \%$ in fresh chicken and beef burger. The occurrence frequency $\%$ of $E$. coli was found to be high in chicken/beef burger samples $(6.25 \%)$, and then slightly decreased to $5.21 \%, 4.68 \%$ and $4.17 \%$ in frozen meat, hotdog/sausage and fresh fish samples, respectively. The processed preserved (chicken/beef luncheon and pastrami) and frozen chicken possessed the lowest presence of foodborne pathogens. This study recommends the use of 7plex-PCR detection system for the rapid and accurate detection of some Enterobacteriaceae pathogens is inexpensively and thus could be used for the regular monitoring of food quality.
\end{abstract}

Key words: Multiplex PCR, Enterobacteriaceae, Foodborne pathogens.

\section{INTRODUCTION}

Foodborne disease (FBD) outbreaks are common and often cause considerable morbidity and mortality. Foodborne illnesses are infections or irritations of the gastrointestinal tract caused by food or beverages that contain harmful bacteria, viruses, molds, worms and protozoa. The two most common types of food borne diseases are intoxication and infection. Intoxication occurs when toxin produced by the pathogens cause food poisoning, while infection is caused by the ingestion of food containing pathogens (Grant et al., 2008). When the toxin ingested along with the food, it gives rise to the Food Poisoning Syndrome (Havelaar et al., 2015). Transmission and sources of foodborne diseases are from plant surfaces, animals, water, sewage, air, soil or from food handlers during handling and processing (Bean et al., 1990).

Enterobacteriaceae foodborne pathogens as Salmonella species, Proteus species and some serotypes of Escherichia coli continue to be the major pathogens associated with food poisoning outbreaks. Also, Klebsiella pneumoniae is most commonly associated with 


\section{Ahmed K.A. El-Sayed et al.}

nosocomial infections and most frequently causes pneumonia, urinary tract, central nervous system, hepatic infections, wound and/or blood infections (Podschun et al., 1998) and associated with intestinal infections, with symptoms of diarrhea if enterotoxigenic strains are involved (Klipstein and Engert 1976). Salmonella species causes enteric fever in humans and fatal diseases, gastroenteritis and other extra-intestinal complications (D'Aoust, 1989). Enterobacter species are widely distributed in nature found in the soil, water, dairy products, and in the intestines of animals as well as humans (Euzéby et al., 1997).

With the continuing impact of these pathogens on human and animal health, the need for rapid and accurate detection methods for these organisms both in environmental and clinical samples remains high. Moreover, identification of enterobacteriaceae members including E. coli, Salmonella sp., Proteus sp., Enterobacter sp. and Klebsiella sp., is important for surveillance, prevention and control of food-borne diseases. An accurate and rapid procedure for identification would help identify the sources, reservoirs and or their transfer through food chain.

Conventional methods for pathogen detection based on culturing, selective enrichment and biochemical testing are generally cumbersome, inefficient, labor intensive and time consuming take 3-5 days or more (Miescier et al., 1992; D’Aoust, 1989). In contrast, advanced DNA-based methods, such as DNA hybridization and PCR-based assays (mono and multiplex PCR, real-time PCRs), fluorescent DNA probes, microarrays and DNA fingerprinting techniques, ELISA-based assays are rapid and highly sensitive. Those techniques could be applied universally for identification of food-borne pathogens because they rely on the nucleic acid composition of the bacterium instead of their phenotypic expressions that may be variable under culture conditions (Olsen et al., 1995; Batt, 1997).

The PCR represents a rapid procedure with both high sensitivity and specificity for the immediate detection, identification of specific pathogenic bacteria from various food matrices as individual detection (monoplex PCR) (Lantz et al., 1994; Hill et al., 1996) and multiplex PCR (Way et al., 1993; Soumet et al., 1999). The invasion antigen gene (invA) was used for detection of Salmonella sp. (Rahn et al.,1992; Malkawi and Gharaibeh 2003; Trafny et al., 2006; Litty et al. 2013). The multiplex PCR had been used successfully for detection of Salmonella enterica and differentiate all four Shigella spp using invA gene and ipaH1 gene, respectively (Radhika et al., 2014). The B-glucuronidase (uidA) was specific for E. coli detection (Li et al. 2005; Anklam et al. 2012; Litty et al. 2013). A certain and specific primers derived from gyrA gene was used for detection of Klebsiella spp (Yogesh et al. 2011; Brisse and Verhoef, 2001). Furthermore, one can differentiate between $K$. pneumonia and $K$. oxytoca using certain primers for amplifying rpoB and pehX target genes, respectively (Kovtunovych et al. 2003; Yogesh et al. 2011). Proteus species were detected using a target segment of ATP synthase subunit beta (atpD) gene ShuilianBi et al. 2013). The simultaneous multiplex PCR detection for five different food borne pathogens (Jeong et al., 2007; Zheng et al., 2013; Litty et al., 2013), and six food borne pathogens (Beili et al., 2013) were performed successfully. Unfortunately, the detection of more than six organisms in the same reaction by using multiplex PCR is quite obstacle. This study tried to optimize a standard condition for 7plex-PCR in order to rapid detect seven target food born Enterobacteriaceae pathogens.

\section{MATERIALS AND METHODS \\ Food samples, bacterial isolation and culturing}

Four main types of food samples were collected from different stores and markets at Damietta County, Egypt. The food samples which suspected having contamination with Enterobacteriaceae pathogens comprised 40 fresh food samples (chicken, beef meat and fish), 50 


\section{Simultaneous detection of seven foodborne Enterobacteriaceae pathogens using multiplex PCR}

frozen food samples (chicken, beef meat and filet of-fish), 60 processed frozen food samples (hotdog/sausage and chicken/beef burger), and 42 processed preserved food samples (chicken/beef luncheon and pastrami).

Presumptive Enterobacteriaceae colonies were selected and isolated on three chromogenic differential media including Salmonella-Shigella (SS), Eosin Methylene Blue (EMB) (Levine's formulation), and Triple Sugar Iron (TSI) media. 1gm of food sample was added to $5 \mathrm{~mL}$ of sterile nutrient broth media then whirly mixed and incubated for $2 \mathrm{~h}$ at $30^{\circ} \mathrm{C}$ for enrichment. $200 \mathrm{~mL}$ of each serial dilution of each sample were speeded on the previously mentioned media. After overnight incubation, the resulting colonies were examined, isolated and purified as a single colony for further identification. Another $200 \mathrm{~mL}$ was centrifuged and kept in $-20^{\circ} \mathrm{C}$ freezer for chromosomal DNA extraction and PCR analysis.

The isolated bacterial strains were identified morphologically, physiologically and biochemically according to Bergey`s Manual of Systematic Bacteriology (Bernner and Farmer 1984; Bercovier and Mollaret 1984; Patrick and Francine 1984; Rowe and Gross 1984).

\section{Standard bacterial strains}

The reference bacterial strains (E. coli, Proteus sp., Salmonella sp., Enterobacter sp., Klebsiella sp., Klebsiella pneumonia and Klebsiella oxytoca) were obtained from the culture collection of Microbiology Laboratory, Faculty of Science, Damietta University.

\section{DNA Extraction}

Chromosomal DNA was extracted by phenol/chloroform technique according to procedure modified from (Ausubel et al., 1996). 1.5mL of bacterial cell suspension was centrifuged at $6.500 \mathrm{rpm}$ for $5 \mathrm{~min}$. The pellet was suspended in $1 \mathrm{ml}$ SET buffer $(20 \%$ sucrose, $50 \mathrm{mM}$ EDTA, 50mM Tris-HCl, pH 7.6). The pellet was re-suspended in $100 \mu \mathrm{L}$ buffer (SET buffer + Lysozyme), vortex and followed by the addition of $2 \mu \mathrm{L}$ RNase. After incubation at $37^{\circ} \mathrm{C}$ for $10 \mathrm{~min}, 500 \mu \mathrm{L}$ TE buffer $(10 \mathrm{mM}$ Tris-HCl, $\mathrm{pH} 7.6,0.2 \mathrm{mM}$ EDTA) and $70 \mu \mathrm{L}$ of $10 \%$ sodium dodecyl sulfate were added. DNA was extracted with $500 \mu \mathrm{L}$ of phenol/ chloroform/isoamyl alcohol solution (25:24:1), centrifuged at $6.500 \mathrm{rpm}$ for 5min and precipitated with isopropanol. The DNA was harvested by centrifugation at $6.500 \mathrm{rpm}$ for $10 \mathrm{~min}$, washed with $500 \mu \mathrm{L}$ of $75 \%$ cold ethanol and the DNA pellet was suspended in 1/10 TE buffer and stored at $-20^{\circ} \mathrm{C}$ until used for PCR amplification.

\section{Primers and PCR conditions}

The oligonucleotide sequence of the primers and the expected sizes for each pathogen are represented in Table 1. For optimization of the multiplex PCR amplification, $30 \mathrm{pmole}$ of each primer, $2 \mu \mathrm{L}$ of extracted chromosomal DNA and $25 \mu \mathrm{L} 2 \mathrm{x}$ Mytaq Red Mix (BIOLINE) were used. The final volume of the reaction mixture was adjusted to $50 \mu \mathrm{L}$ with water free nuclease. The multiplex PCR reactions were performed in the thermal cycler (TECHNE TC-312, UK) with initial denaturation at $95^{\circ} \mathrm{C}$ for 5 minutes followed by 35 cycles of denaturation at $95^{\circ} \mathrm{C}$ for 30 seconds, primer annealing at $58^{\circ} \mathrm{C}$ for 1 minute, primer extension at $72^{\circ} \mathrm{C}$ for $1: 30$ minute, and the final extension at $72^{\circ} \mathrm{C}$ for 10 minutes. 
Ahmed K.A. El-Sayed et al.

Table 1. List of primers and the expected amplicon sizes for each target gene and pathogen.

\begin{tabular}{|c|c|c|c|c|c|}
\hline Primer & Sequence $\left(5^{\prime}-3^{\prime}\right)$ & $\begin{array}{l}\text { Amplicon } \\
\text { size (bp) }\end{array}$ & $\begin{array}{l}\text { Target } \\
\text { gene }\end{array}$ & $\begin{array}{l}\text { Bacterial } \\
\text { strain }\end{array}$ & Reference \\
\hline $\begin{array}{l}\text { UidA-F } \\
\text { UidA-R }\end{array}$ & $\begin{array}{l}\text { For: GTCACGCCGTATGTTATTG } \\
\text { Rev: CCAAAGCCAGTAAAGTAGAAC }\end{array}$ & 530 & uidA & E. coli & $\begin{array}{l}\text { Litty, et al. } \\
\text { (2013) }\end{array}$ \\
\hline $\begin{array}{l}\text { AtpD-F } \\
\text { AtpD-R }\end{array}$ & $\begin{array}{l}\text { For:GTATCATGAACGTTCTGGGTAC } \\
\text { Rev: TGAAGTGATACGCTCTTGCAG }\end{array}$ & 595 & atpD & Proteus sp. & $\begin{array}{l}\text { Shui-lianBi, et } \\
\text { al. (2013) }\end{array}$ \\
\hline $\begin{array}{l}\text { InvA-F } \\
\text { InvA-R }\end{array}$ & $\begin{array}{l}\text { For: GTGAAATTATCGCCACGTTCGGGCAA } \\
\text { Rev: TCATCGCACCGTCAAAGGAACC }\end{array}$ & 284 & invA & Salmonella sp. & $\begin{array}{l}\text { Rahn, et al. } \\
(1992)\end{array}$ \\
\hline $\begin{array}{l}\text { 16s DNA-F } \\
\text { 16s DNA-R }\end{array}$ & $\begin{array}{l}\text { For: ATGTCTGGGAAACTGCCTGATG } \\
\text { Rev: CGGGTAACGTCAATAGACAAGG }\end{array}$ & 372 & $\begin{array}{l}16 \mathrm{~S} \\
\text { rRNA }\end{array}$ & $\begin{array}{l}\text { Enterobacter } \\
s p .\end{array}$ & $\begin{array}{l}\text { Tajbakhsh, et } \\
\text { al. (2015) }\end{array}$ \\
\hline $\begin{array}{l}\text { GyrA-F } \\
\text { GyrA-R }\end{array}$ & $\begin{array}{l}\text { For: CGCGTACTATACGCCATGAACGTA } \\
\text { Rev: ACCGTTGATCACTTCGGTCAGG }\end{array}$ & 441 & gyrA & Klebsiella sp. & $\begin{array}{l}\text { Brisse and } \\
\text { Verhoef (2001) }\end{array}$ \\
\hline $\begin{array}{l}\text { RpoB-F } \\
\text { RpoB-R }\end{array}$ & $\begin{array}{l}\text { For: CAACGGTGTGGTTACTGACG } \\
\text { Rev: TCTACGAAGTGGCCGTTTTC }\end{array}$ & 108 & rров & $\begin{array}{l}\text { Klebsiella } \\
\text { pneumonia }\end{array}$ & $\begin{array}{l}\text { Yogesh, et al. } \\
(2011)\end{array}$ \\
\hline $\begin{array}{l}\text { PehX-F } \\
\text { PehX-R }\end{array}$ & $\begin{array}{l}\text { For: GATACGGAGTATGCCTTTACGGTG } \\
\text { Rev: TAGCCTTTATCAAGCGGATACTGG }\end{array}$ & 343 & $\operatorname{peh} X$ & $\begin{array}{l}\text { Klebsiella } \\
\text { oxytoca }\end{array}$ & $\begin{array}{l}\text { Kovtunovych, } \\
\text { et al. (2003) }\end{array}$ \\
\hline
\end{tabular}

Agarose gel electrophoresis and DNA detection

The detection of genomic DNA and size of PCR products were examined by agarose gel electrophoresis. 3\% agarose was dissolved in TAE buffer $\mathrm{pH} 8.0(0.04 \mathrm{M}$ Tris-acetate and $0.001 \mathrm{M}$ EDTA). $2 \mu \mathrm{L}$ of ethidium bromide $(10 \mathrm{mg} / \mathrm{mL})$ was added for DNA staining. Usually $2 \mu \mathrm{L}$ of loading buffer $(0.25 \%$ Bromophenol blue, $70 \%$ glycerol, $10 \mathrm{mM}$ Tris- $\mathrm{HCl} \mathrm{pH} 7.0)$ was added to the sample. 50bp DNA Ladder was used as molecular marker. The DNA on the gel was visualized by UV transilluminator.

\section{Sensitivity of multiplex PCR primers}

The previous sets of primers were subjected to study their sensitivity towards the minimal cell count detection. In order to perform that, $1 \mathrm{ml}$ serial dilutions $\left(10^{0}\right.$ to $\left.10^{-5}\right)$ of the reference bacterial strains were set from their overnight cultures on nutrient broth medium. 100 $\mu$ l aliquots of each dilution (in triplicates) was cultured on nutrient agar plates for colony forming unit (cfu) count. Other $100 \mu \mathrm{l}$ aliquots of the same dilutions was centrifuged for bacterial cell collection. The DNA from each pellet was extracted and then subjected to PCR analysis. The resulting PCR products were compared with the corresponding cfu count for each dilution.

\section{RESULTS \\ Identification and distribution of the foodborne pathogens}

A total of 192 food samples comprised 40 fresh food samples (chicken, beef meat and fish), 50 frozen food samples (chicken, beef meat and filet-o-fish), 60 processed frozen food samples (hotdog/sausage and chicken/beef burger), and 42 processed preserved food samples (chicken/beef luncheon and pastrami). The classical identification based on morphological, physiological and biochemical characteristics, in addition to their distribution within the different types of food samples were listed in Table (2) and Figure (1). Generally, Salmonella is the most dominant genus, which distributed within most of all types of food having the maximum occurrence frequency reached $6.77 \%$ in hotdog and sausage samples followed by chicken and 
beef burger with $5.21 \%$. The frequency of $E$. coli with found to be high in fresh fish samples $(4.17 \%)$, and then slightly decline to $3.13 \%$ in frozen chicken and meat samples.

\section{The multiplex PCR}

The seven sets of oligonucleotide primers were examined separately using reference bacterial strains as mentioned in the material and methods section. The amplified DNA fragments of the expected molecular for each strain was examined by agarose gel electrophoresis as shown in Figure 2. The individual PCR products were represented in lane 1-7, while the multiplex PCR for the seven tested sets of primers was in lane 8 .

\section{Sensitivity of the optimized multiplex PCR}

The sensitivity of the multiplex PCR assay was determined (Fig. 3). The results of multiplex PCR assay were able to detect the cultivable pathogens up to 5-10 cfu bacterial count which found in the $10^{-4}$ culture dilution of each reference bacterial strains. The culture dilution $10^{-5}$ containing less than 5 cfu could not detect any amplification for the targeted DNA.

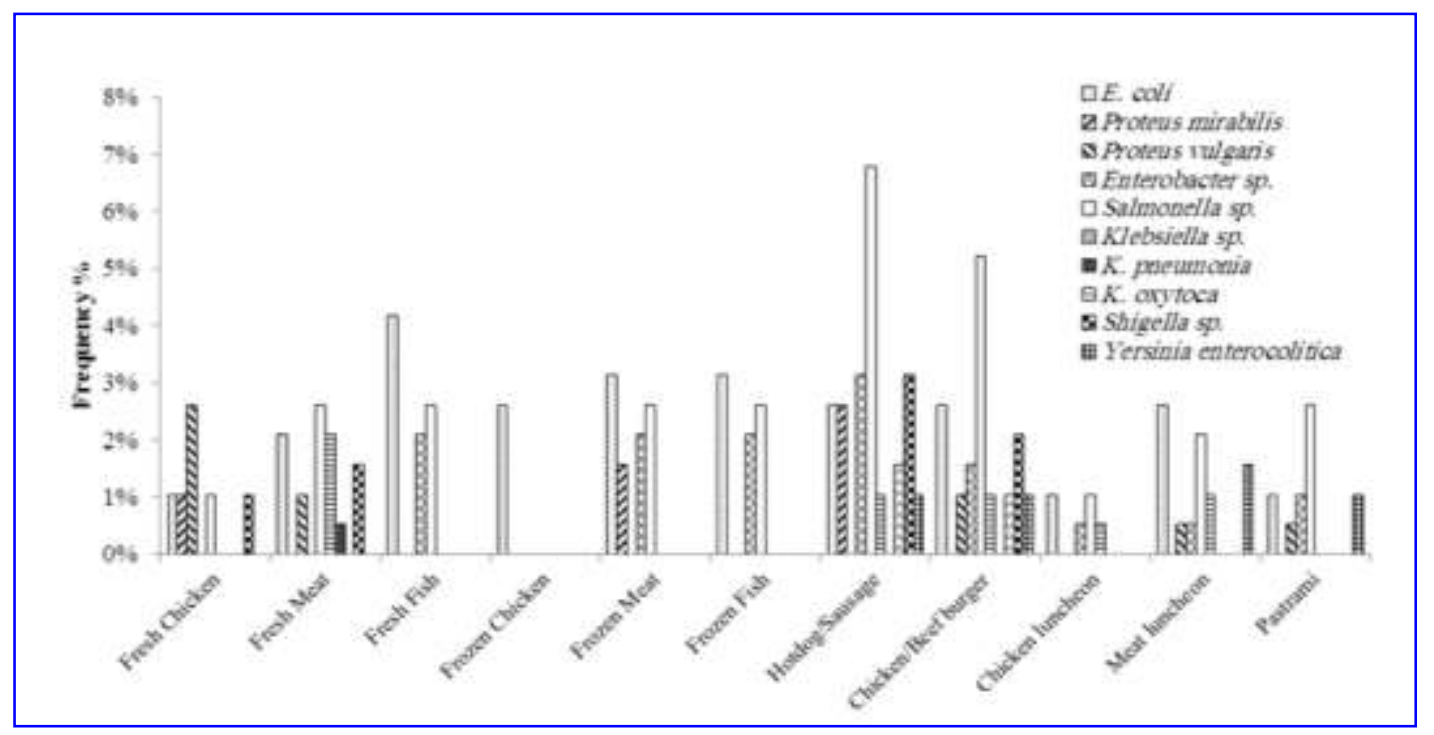

Fig. 1. The occurrence frequency and distribution of the identified bacterial pathogens found in the different types of food samples. 
Ahmed K.A. El-Sayed et al.

Table 2. The occurrence frequency and distribution of the identified bacterial pathogens found in the different types of food sample.

\begin{tabular}{|c|c|c|c|c|c|c|c|c|c|c|c|c|}
\hline \multirow{2}{*}{\multicolumn{2}{|c|}{ Type of anmples }} & \multicolumn{3}{|c|}{ Fresh } & \multicolumn{3}{|c|}{ Frenen } & \multicolumn{2}{|c|}{ Procemed fruorm } & \multicolumn{3}{|c|}{ Frocened prenerved } \\
\hline & & Caickes & Meat & Find & Chickn & Meat & Finth & $\begin{array}{c}\text { Hotdogrsa } \\
\text { waye }\end{array}$ & $\begin{array}{c}\text { CNicles: } \\
\text { Beef bartor }\end{array}$ & $\begin{array}{l}\text { Coidek } \\
\text { Inscibesh }\end{array}$ & $\begin{array}{c}\text { Meat } \\
\text { teacheod }\end{array}$ & Pantrani \\
\hline \multicolumn{2}{|c|}{ Se. of mainples } & 11 & 13 & 16 & II & 20 & 19 & 30 & 30 & 12 & 15 & 15 \\
\hline \multicolumn{2}{|c|}{ Xe. of negrattre samplet } & 2 & 4 & 3 & 6 & 5 & 6 & 5 & 9 & 5 & 6 & 7 \\
\hline \multirow{10}{*}{ 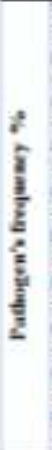 } & Ecill & 1.045 & 218 & 4.174 & $2.5 \%$ & 3.134 & 3.134 & 2.676 & 2.64 & 1044 & $2.6 \%$ & 1048 \\
\hline & Protrut ninebeitis & $104 \mathrm{~s}$ & $\operatorname{los}$ & OA & es & 1.564 & $\cos$ & 264 & $0 \%$ & oss & $0 \%$ & $9 \%$ \\
\hline & Protent valgantr & $26 \mathrm{~s}$ & 1045 & os & os & os & os & os & $1.04 \%$ & os & $0.52 \%$ & 0.585 \\
\hline & Enterobucter $\%$ & 04 & 05 & 2.16 & oss & 2.16 & 218 & $313 \mathrm{~N}$ & $156 \mathrm{~s}$ & 0.524 & 0.528 & 1046 \\
\hline & Selmusella op & $104 \%$ & 2.606 & $20 \%$ & os & 20 & 258 & 6774 & 3215 & $1.04 \%$ & 2.14 & 2.05 \\
\hline & Medriellap & 066 & 216 & 066 & oes & 096 & $\infty$ & 1.045 & $100 \%$ & 0.525 & $104 \%$ & $0 \%$ \\
\hline & K. pernumuts & 066 & 0.525 & Os & 06 & OA & os & os & os & os & os & 06 \\
\hline & I. evters & os & of & W & es & Ms & os & 1.564 & touss & ots & os & ons \\
\hline & Onitrila & 1045 & $1.56 \%$ & as & es & os & est & 3.134 & 2.15 & os & os & 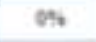 \\
\hline & Yeninda enterecolisicat & os & os & os & ose & ON & os. & $1.04 \%$ & 1.046 & os & $150 \mathrm{~N}$ & 1045 \\
\hline
\end{tabular}

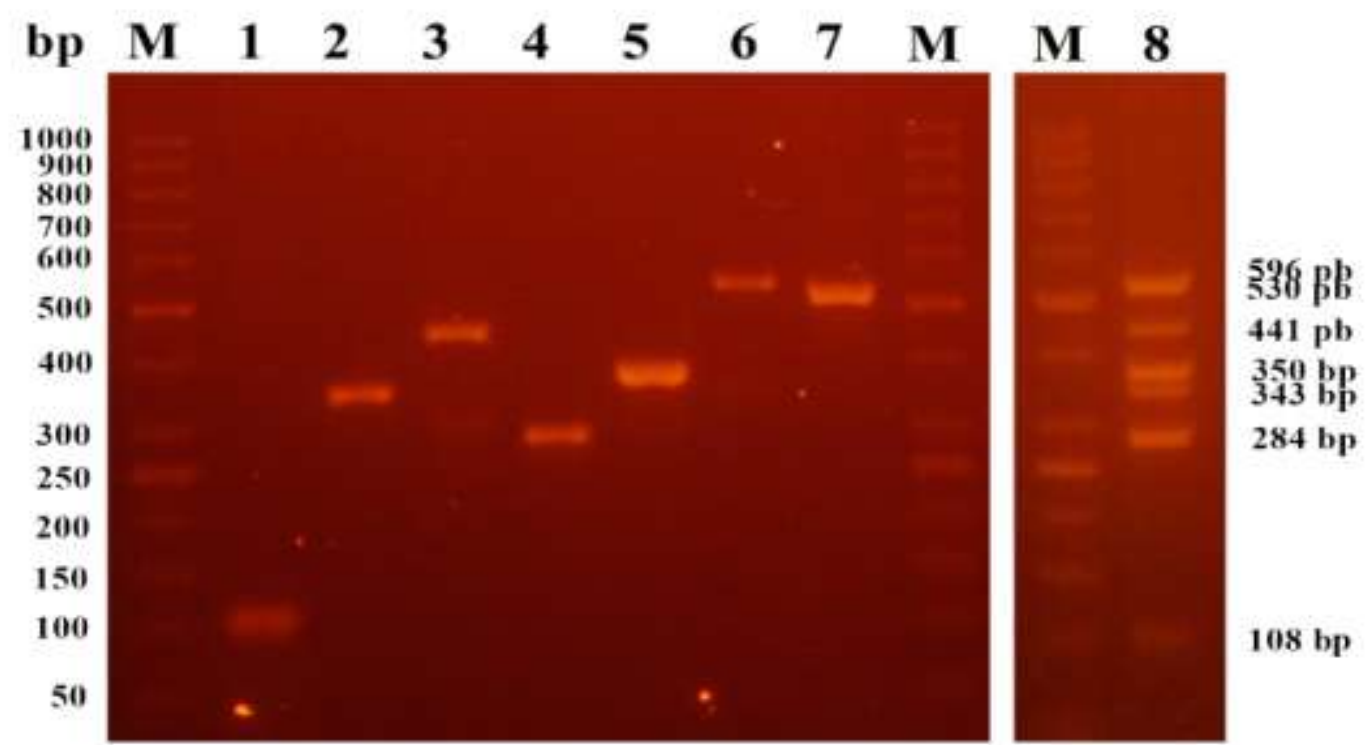

Fig. 2. Agarose gel electrophoresis for the individual PCR amplification of the seven target gene from purified DNA of the standard seven microbial pathogens (lane 1, Klebsiella Pneumonia; lane 2, Klebsiella oxytoca; lane 3, Klebsiella Sp.; lane 4, Salmonella sp.; lane 5, Enterobacter sp.; lane 6, Proteus sp.; lane 7, E. coli) and the multiplex PCR for the all seven gene targets (lane 8). Lane $M$ is the 50 bp DNA marker. 
Simultaneous detection of seven foodborne Enterobacteriaceae pathogens using multiplex PCR

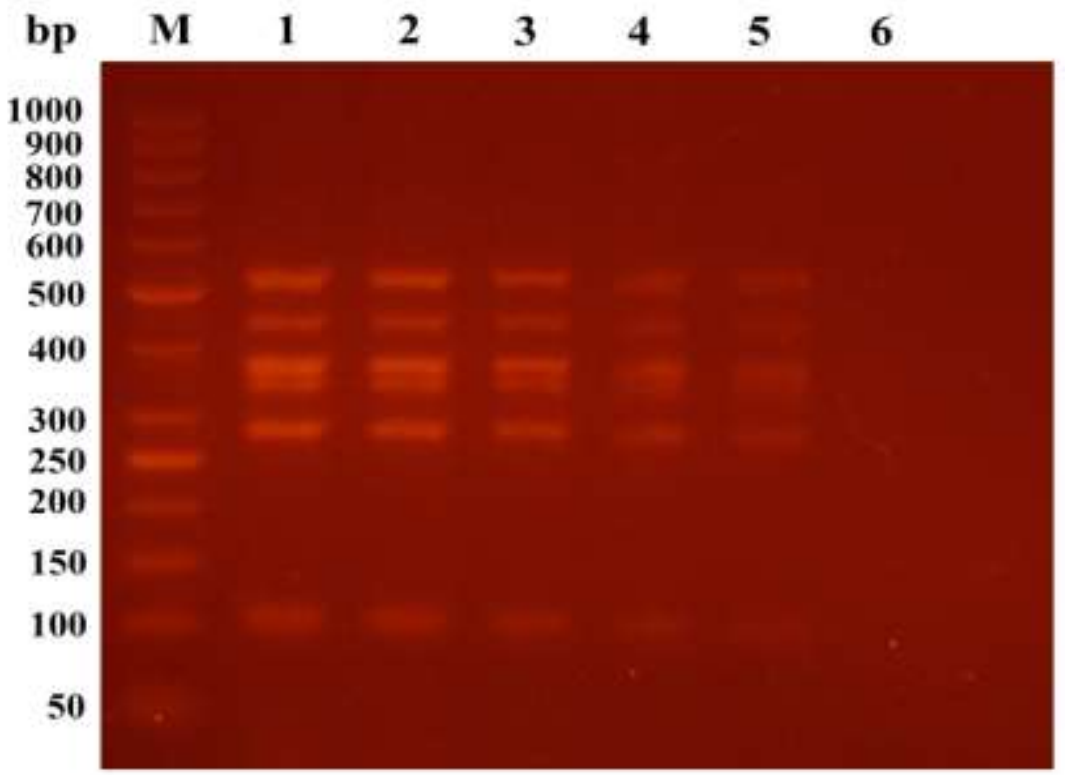

Fig. 3. Sensitivity of the multiplex PCR applied to seven target genes of the standard pathogens. Lanes 1 to 6 , bacterial dilutions, $10^{0}-10^{-5}$, respectively. Lane M, 50 bp DNA marker.

\section{7plex-PCR detection for fresh food pathogens}

The multiplex PCR assay for 40 fresh food samples (chicken, beef meat and fish) is represented in Table 3 and Figure 4 as the sizes of the amplified target DNA for each tested pathogen gave the expected and correct size. Three fresh meat samples were highly contaminated with three pathogens (E. coli, Salmonella sp. and Klebsiella sp.). The species name of Klebsiella in those three samples did not recognize as neither pneumonia nor oxytoca. Both of E. coli, and Salmonella sp. were detected in 4 and 5 fresh chicken and meat samples, respectively. The occurrence frequency \% (Fig. 5) of Salmonella sp. was the highest (25\%) in the meat samples followed by E. coli (20\%) in the fish samples. The presence of $K$. pneumonia was the lowest $(2.5 \%)$ within meat samples, while $K$. oxytoca could not be detected within any fresh food samples.

Table 3. The different multiplex PCR patterns for 40 fresh samples of chicken, beef meat and fish. (+: positive PCR results, ND: not detected samples).

\begin{tabular}{|c|c|c|c|c|c|c|c|c|c|c|c|c|}
\hline Type of samples & & ick & & & & $\mathbf{f} \mathbf{m}$ & & & & & & \\
\hline PCR pattern & 1 & 2 & ND & 3 & 4 & 5 & 6 & ND & 7 & 8 & 9 & ND \\
\hline No. of samples & 4 & 5 & 2 & 3 & 1 & 3 & 4 & 2 & 4 & 4 & 5 & 3 \\
\hline E. coli & + & & & + & + & + & & & + & + & & \\
\hline Proteus sp. & & + & & & & & + & & & & & \\
\hline Enterobacter sp. & & & & & & & & & + & & & \\
\hline Salmonella sp. & + & & & + & & + & + & & & & + & \\
\hline Klebsiella sp. & & & & + & + & & & & & & & \\
\hline Klebsiella pneumonia & & & & & + & & & & & & & \\
\hline
\end{tabular}


Ahmed K.A. El-Sayed et al.

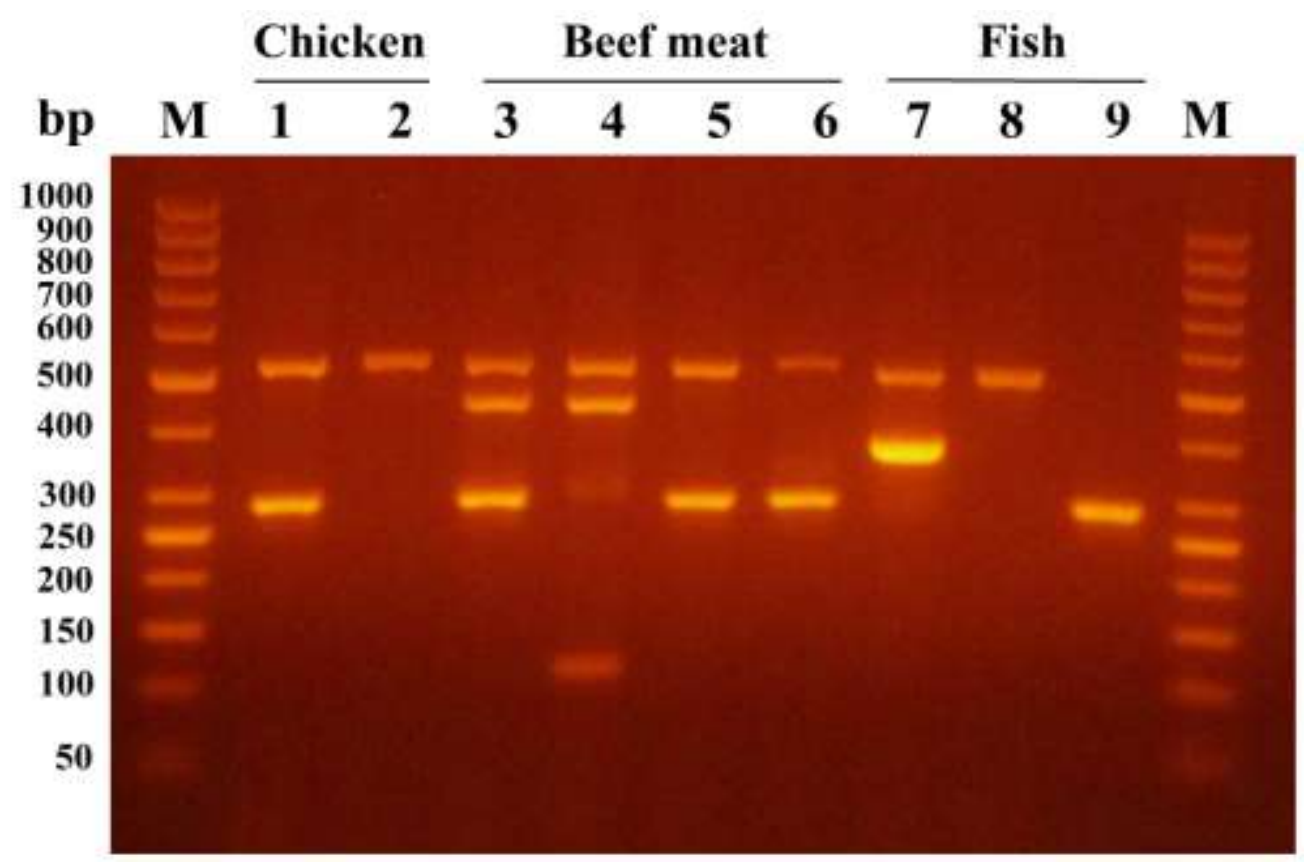

Fig. 4. Agarose gel electrophoresis pattern for the multiplex PCR of contaminated fresh food samples (chicken, beef meat and fish). Lane1, E. coli and Salmonella sp.; lane 2, Proteus sp.; lane 3, E. coli, Klebsiella. sp. and Salmonella sp.; lane 4, E. coli, Klebsiella. sp., K. pneumonia; lane 5, E. coli and Salmonella sp.; lane 6, Proteus sp. and Salmonella sp.; lane 7, E. coli and Enterobacter sp.; lane 8, E. coli; lane 9, Salmonella sp.

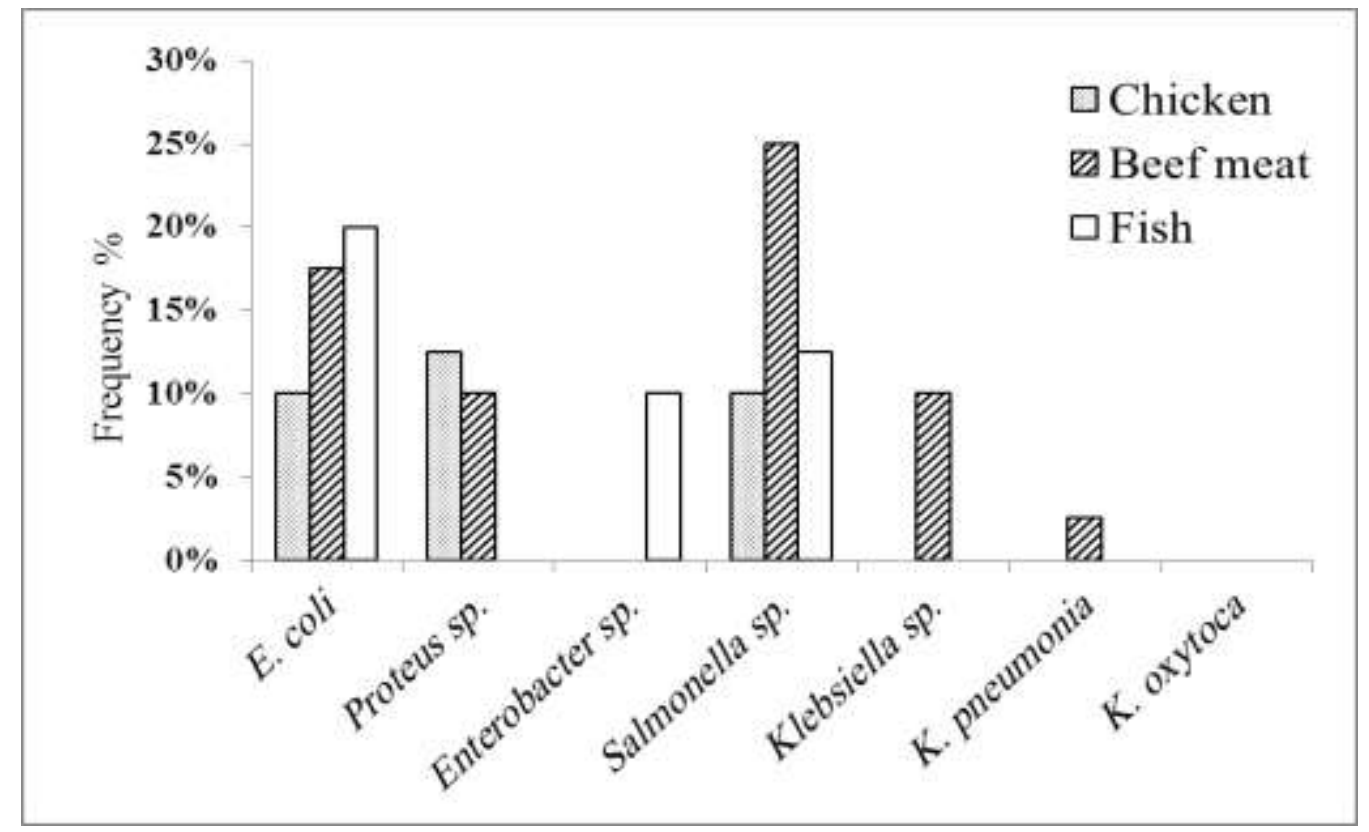

Fig. 5. Frequency percentage of the occurrence for the bacterial pathogens found in $\mathbf{4 0}$ fresh food samples (chicken, beef meat and fish) as detected by the multiplex PCR technique. 
Simultaneous detection of seven foodborne Enterobacteriaceae pathogens using multiplex PCR

\section{7plex-PCR detection for frozen food pathogens}

A total of 50 frozen food samples (chicken, beef meat and filet of fish) were examined by multiplex PCR assay where their patterns are represented in Table 4 and Figure 6. Out of 11 frozen chicken samples, only 5 were contaminated with $E$. coli. Three of meat and two filets of fish frozen samples were contaminated with both of E. coli, and Salmonella sp. as detected by the multiplex PCR. The Enterobacter sp. was found in 4 filets of fish samples and associated with $E$. coli in 4 beef meat samples. The occurrence frequency \% (Fig. 7) of E. coli. was the highest (20\% and $12.5 \%$ ) in the beef meat and filets of fish frozen samples, then decline to $10 \%$ in the chicken samples. In addition, Salmonella sp. was found in beef meat and filet of fish with frequency reached 10\%. The presence of Proteus sp. was the lowest (6\%) within the beef meat samples. The multiplex PCR assay could not detect any species of Klebsiella within the frozen food samples.

Table 4. The different multiplex PCR patterns for 50 frozen samples of chicken, beef meat and filet-o-fish. (+: positive PCR results, ND: not detected samples).

\begin{tabular}{|c|c|c|c|c|c|c|c|c|c|c|c|c|c|}
\hline \multirow{2}{*}{$\frac{\text { Type of samples }}{\text { PCR pattern }}$} & \multicolumn{2}{|c|}{ Chicken } & \multicolumn{6}{|c|}{ Beef meat } & \multicolumn{5}{|c|}{ Filet-o-fish } \\
\hline & 1 & ND & 2 & 3 & 4 & 5 & 6 & ND & 7 & 8 & 9 & 10 & ND \\
\hline No. of samples & 5 & 6 & 3 & 4 & 3 & 3 & 2 & 5 & 2 & 4 & 4 & 3 & 6 \\
\hline E. coli & + & & + & + & & + & & & + & + & & & \\
\hline Proteus sp. & & & & & + & & & & & & & & \\
\hline Enterobacter sp. & & & & + & & & & & & & + & & \\
\hline Salmonella sp. & & & + & & & & + & & + & & & + & \\
\hline
\end{tabular}

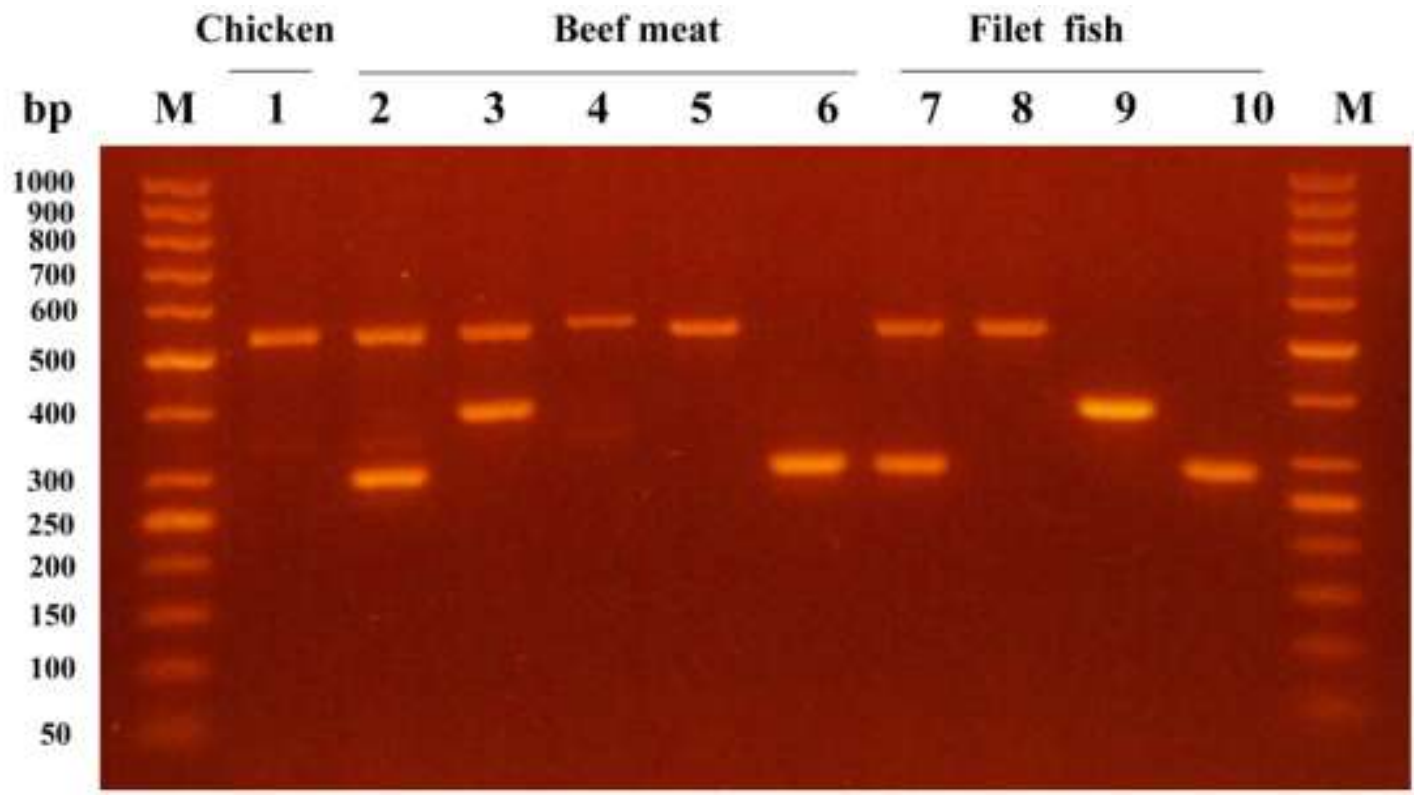

Fig. 6. Agarose gel electrophoresis pattern for the multiplex PCR of contaminated frozen food samples (chicken, beef meat and filet-o-fish). Lane1, $E$. coli; lane 2, E. coli and Salmonella sp.; lane 3, E. coli and Enterobacter sp.; lane 4, Proteus sp.; lane 5, E. coli; lane 6, Salmonella sp.; lane 7, E. coli and Salmonella sp.; lane 8, E. coli; lane 9, Enterobacter sp.; lane 10, Salmonella sp. 
Ahmed K.A. El-Sayed et al.

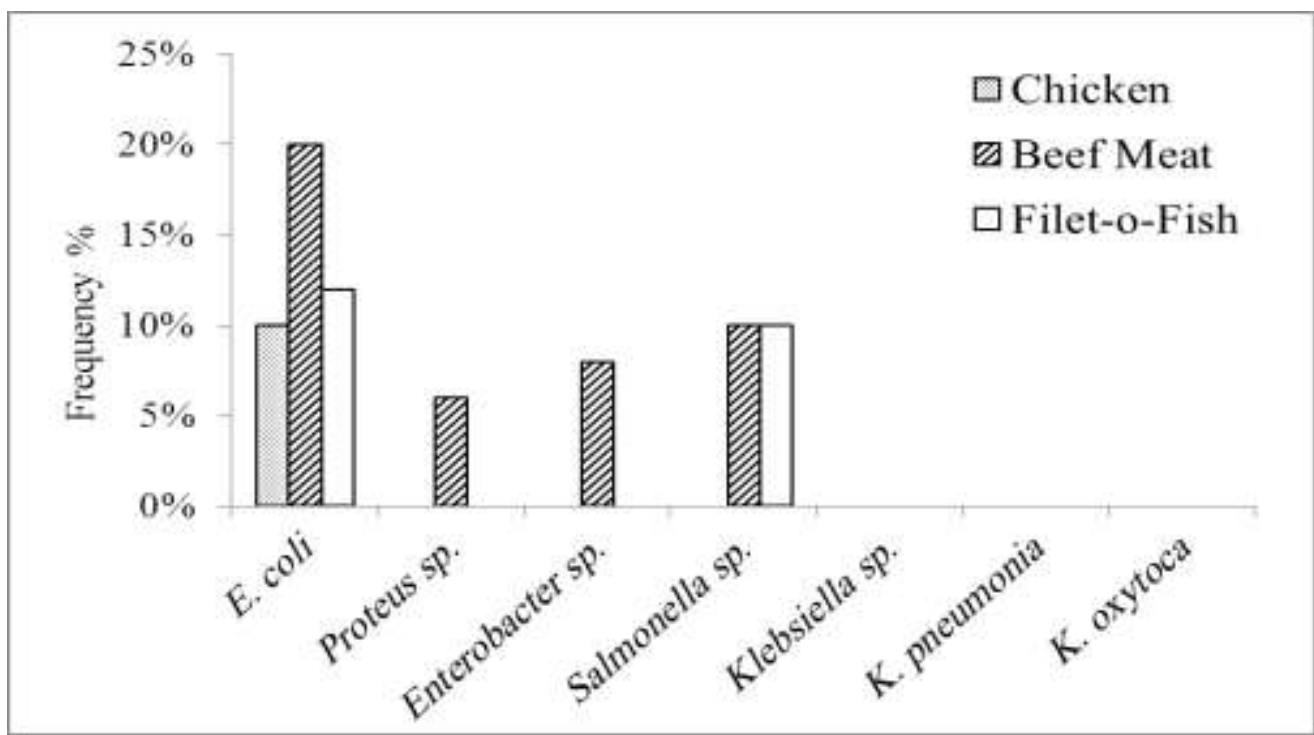

Fig. 7. Frequency percentage of the occurrence for the bacterial pathogens found in $\mathbf{5 0}$ frozen food samples (chicken, beef meat and filet-o-fish) as detected by the multiplex PCR technique.

\section{7plex-PCR detection for processed frozen food pathogens}

Sixty processed frozen food samples of hotdog/sausage and beef/chicken burger were examined by multiplex PCR assay. Their different patterns are represented in Table 5 and Figure 8. The highest contamination with more than individual pathogens were detected in 4 hotdog/sausage samples as they contain three bacterial pathogens (E. coli, Enterobacter sp. and Salmonella sp.), also, 2 beef/chicken burger samples possessed three pathogens included E. coli, Salmonella sp. and Klebsiella oxytoca). The occurrence frequency \% (Figure 9) of Salmonella sp. was the highest (21.7\% and 20\%) followed by E. coli (15\% and 20\%) found in hotdog/sausage and beef/chicken burger samples, respectively. The multiplex PCR could not detect $K$. pneumonia within the processed frozen food samples.

Table 5. The different multiplex PCR patterns for 60 processed frozen samples of hotdog/sausage and beef/chicken burger. (+: positive PCR results, ND: not detected samples).

\begin{tabular}{|c|c|c|c|c|c|c|c|c|c|c|c|c|c|c|}
\hline \multirow{2}{*}{$\begin{array}{l}\text { Type of samples } \\
\text { PCR pattern }\end{array}$} & \multicolumn{7}{|c|}{ Hotdog and sausage } & \multicolumn{7}{|c|}{ Beef and chicken burger } \\
\hline & 1 & 2 & 3 & 4 & 5 & 6 & ND & 7 & 8 & 9 & 10 & 11 & 12 & ND \\
\hline No. of samples & 4 & 3 & 2 & 3 & 5 & 6 & 5 & 2 & 3 & 3 & 2 & 7 & 4 & 9 \\
\hline E. coli & + & + & + & & & & & + & & + & & + & & \\
\hline Proteus sp. & & & & & + & & & & & & + & & & \\
\hline Enterobacter sp. & + & & + & & & & & & + & & & & & \\
\hline Salmonella sp. & + & + & & & & + & & + & + & + & & & + & \\
\hline Klebsiella sp. & & & & + & & & & + & & & & & & \\
\hline Klebsiella oxytoca & & & & + & & & & + & & & & & & \\
\hline
\end{tabular}


Simultaneous detection of seven foodborne Enterobacteriaceae pathogens using multiplex PCR

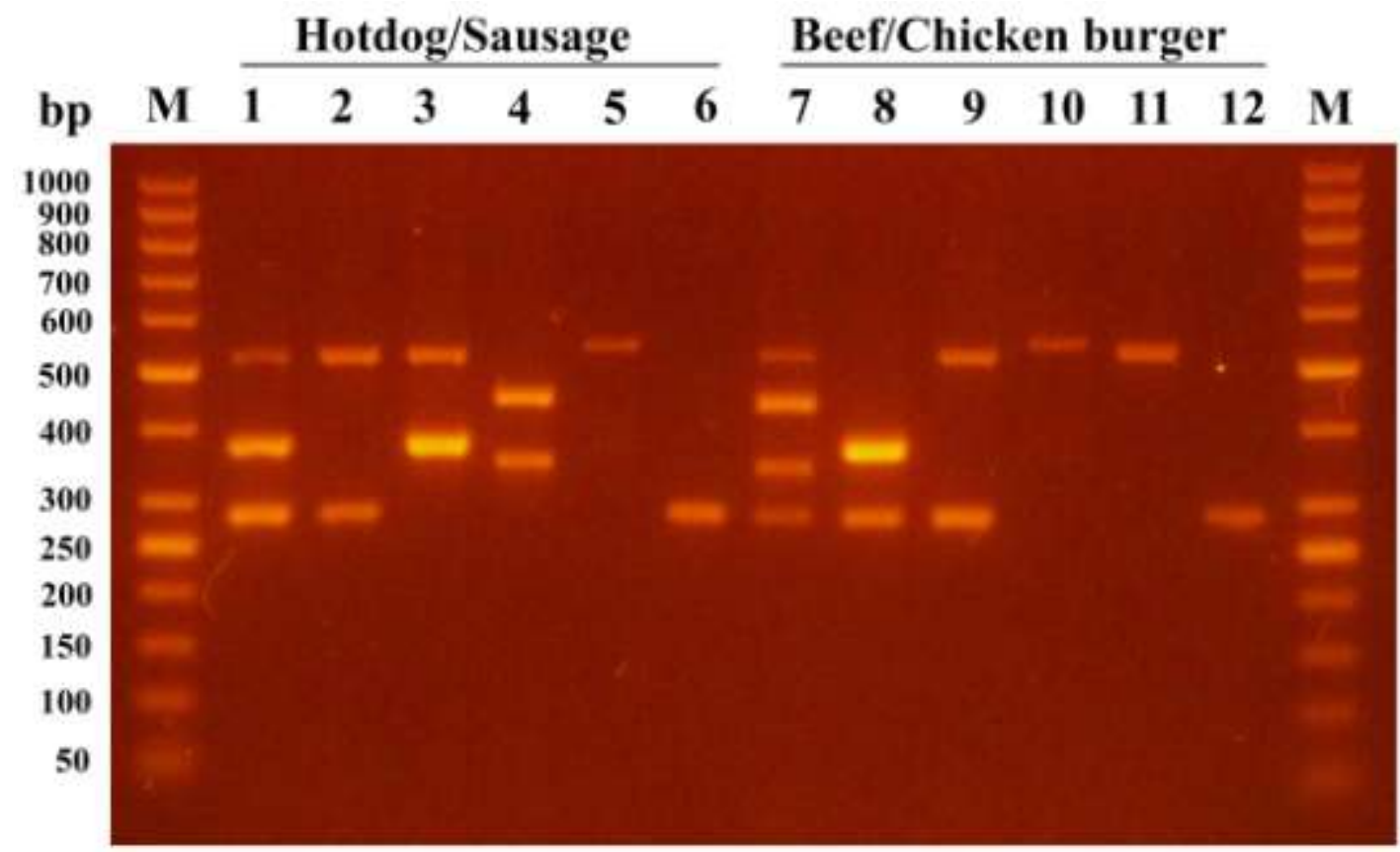

Fig. 8. Agarose gel electrophoresis pattern for the multiplex PCR of contaminated processed food samples (hotdog/sausage and beef/chicken burger). Lane1, E. coli, Enterobacter sp. and Salmonella sp.; lane 2, E. coli and Salmonella sp.; lane 3, E. coli and Enterobacter sp.; lane 4, Klebsiella sp. and Klebsiella oxytoca; lane 5, Proteus sp.; lane 6, Salmonella sp.; lane 7, E. coli, Salmonella sp., Klebsiella sp. and Klebsiella oxytoca; lane 8, Enterobacter sp. and Salmonella sp.; lane 9, E. coli and Salmonella sp.; lane 10, Proteus sp.; lane 11, E. coli; lane 12, Salmonella sp.

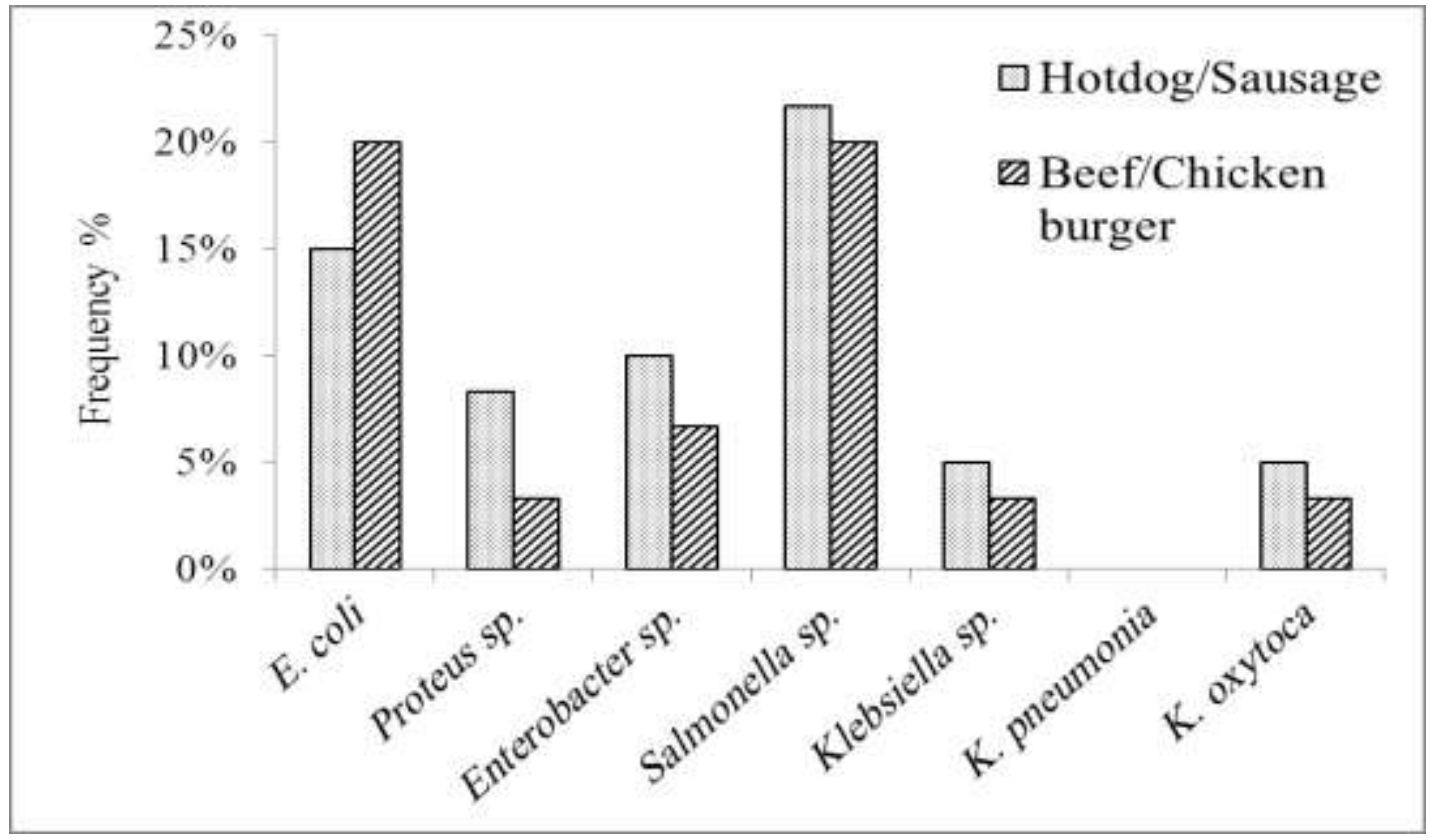


Ahmed K.A. El-Sayed et al.

Fig. 9. Frequency percentage of the occurrence for the bacterial pathogens found in 60 processed food samples (hotdog/sausage and beef/chicken burger) as detected by the multiplex PCR technique.

7plex-PCR detection for processed preserved food pathogens

The different multiplex PCR patterns for 42 processed preserved food samples (chicken luncheon, meat luncheon and pastrami) are represented in Table (6) and Figure (10). Two meat luncheon samples were highly contaminated with three different pathogens comprise E. coli, Salmonella sp. and Klebsiella sp., while another two samples of meat luncheon and pastrami were contaminated with $E$. coli, and Salmonella sp. One samples of chicken luncheon contained E. coli, and Enterobacter sp. The other samples were either contaminated with individual pathogen or not contaminated as assayed by the multiplex PCR technique. The frequency $\%$ of pathogens presence within the processed preserved food samples in Figure 11 showed that the E. coli possessed the highest frequency (16.7\%) in meat luncheon followed by Salmonella sp. (11.9\%) in pastrami samples. The multiplex PCR could not detect $K$. pneumonia and $K$. oxytoca within the processed preserved food samples.

Table 6. The different multiplex PCR patterns for 42 processed preserved samples of chicken luncheon, meat luncheon and pastrami. (+: positive PCR results, ND: not detected samples).

\begin{tabular}{|c|c|c|c|c|c|c|c|c|c|c|c|c|c|c|c|}
\hline \multirow{2}{*}{$\begin{array}{l}\text { Type of samples } \\
\text { PCR pattern }\end{array}$} & \multicolumn{4}{|c|}{ Chicken luncheon } & \multicolumn{6}{|c|}{ Meat luncheon } & \multicolumn{5}{|c|}{ Pastrami } \\
\hline & 1 & 2 & 3 & ND & 4 & 5 & 6 & 7 & 8 & ND & 9 & 10 & 11 & 12 & ND \\
\hline No of samples & 1 & 1 & 2 & 8 & 2 & 2 & 1 & 3 & 1 & 6 & 2 & 1 & 2 & 3 & 7 \\
\hline E. coli & + & + & & & + & + & & + & & & + & & & & \\
\hline Proteus sp. & & & & & & & + & & & & & + & & & \\
\hline Enterobacter sp. & + & & & & & & & & + & & & & + & & \\
\hline Salmonella sp. & & & + & & + & + & & & & & + & & & + & \\
\hline Klebsiella sp. & & + & & & + & & & & & & & & & & \\
\hline
\end{tabular}

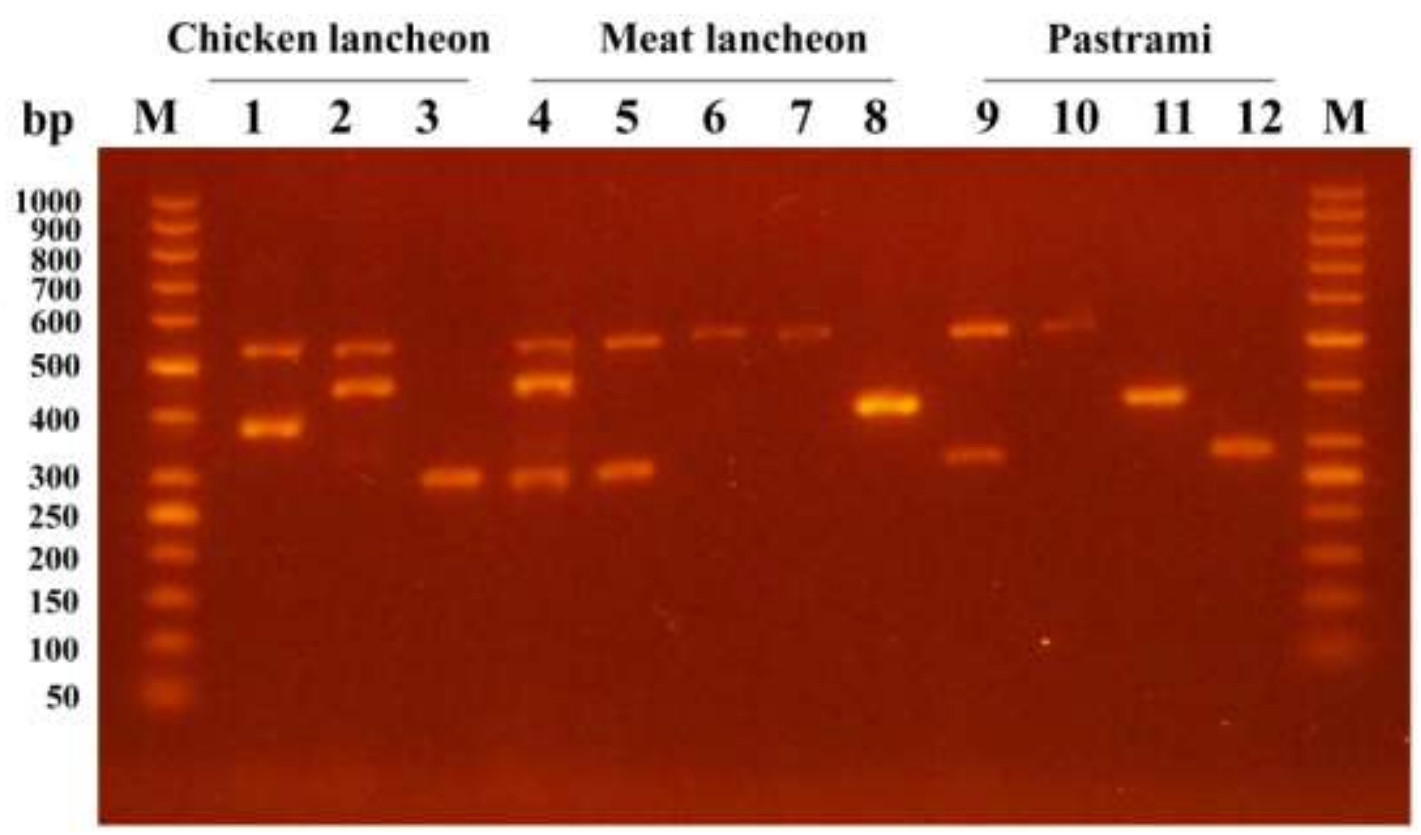

Fig. 10. Agarose gel electrophoresis pattern for the multiplex PCR of contaminated preserved processed food samples (chicken luncheon, meat luncheon and pastrami). Lane1, E. coli and Enterobacter sp.; lane 2, E. coli 
and Klebsiella sp.; lane 3, Salmonella sp.; lane 4, E. coli and Salmonella sp. and Klebsiella sp.; lane 5, E. coli and Salmonella sp.; lane 6, Proteus sp.; lane 7, E. coli; lane 8, Enterobacter sp.; lane 9, E. coli and Salmonella sp.; lane 10, Proteus sp.; lane 11, Enterobacter sp.; lane 12, Salmonella sp.

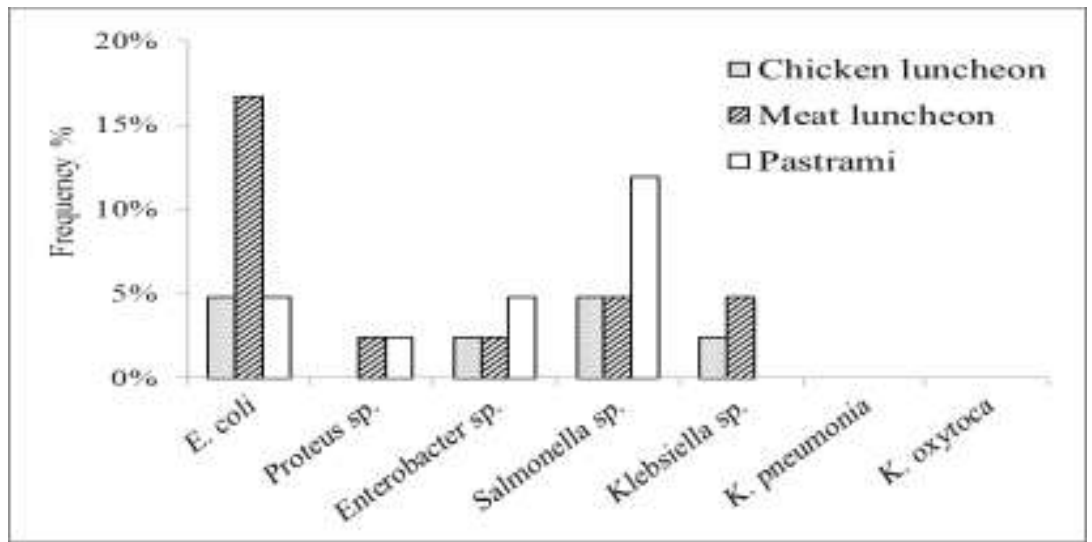

Fig. 11. Frequency percentage of the occurrence for the bacterial pathogens found in 42 preserved processed food samples (chicken luncheon, meat luncheon and pastrami) as detected by the multiplex PCR technique.

Overall distribution of the pathogens detected by 7plex-PCR

Generally, the multiplex PCR examination of 192 different food samples revealed that it is slightly different from their distribution based on the cultural and classical identification. The resulting occurrence frequency $\%$ of the pathogens detected by m-PCR is represented in Figure (12). The Salmonella is the most dominant genus, which distributed within most of all types of food having the maximum occurrence frequency reached $6.77 \%$ in hotdog and sausage samples followed by $5.21 \%$ in fresh chicken and beef burger. The frequency $\%$ of $E$. coli was found to be high in Chicken/Beef burger samples (6.25\%), and then slightly decreased to $5.21 \%, 4.68 \%$ and $4.17 \%$ in frozen meat, hotdog/sausage and fresh fish samples, respectively. Generally, the processed preserved (chicken/beef luncheon and pastrami) and frozen chicken possessed the lowest presence of foodborne pathogens.

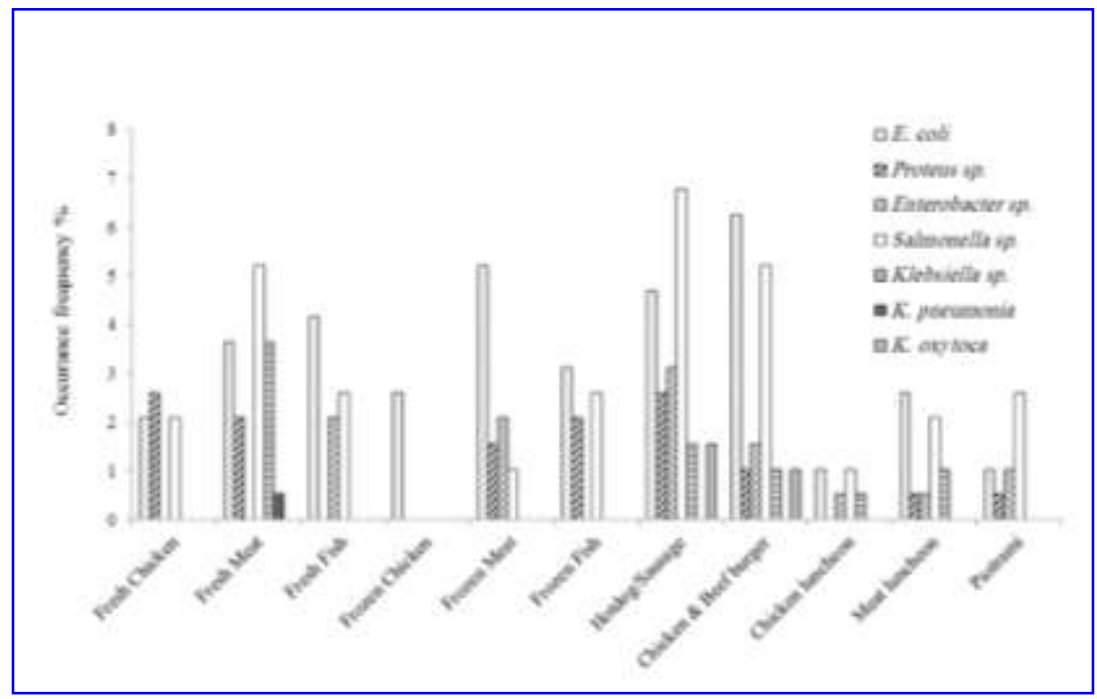

Fig. 12. Occurrence frequency percentages and distribution of the bacterial pathogens detected by multiplex PCR within the different food samples. 


\section{Ahmed K.A. El-Sayed et al.}

\section{DISCUSSION}

Despite the improvements in food processing hygiene practices in recent years, the occurrence of foodborne pathogenic microorganisms is still commonplace. Certain members of the family Enterobacteriaceae are predominant pathogens that found in raw and processed food products and this presence demands prompt investigation (Anbazhagan et al., 2010). Therefore, appropriate methods could be optimized and applied to routine monitoring for pathogens in food and food-processing environments to improve disease control and reduce risks to human health (Moon et al., 2004). The conventional methods of isolation and identification of these pathogens primarily depends on selective media followed by a battery of biochemical tests that are laborious, costly and time consuming (Radji et al., 2010). The multiplex PCR strategy has the potential of being relatively low-cost assays with the additional advantages being reliable and rapid (Hübner et al., 1992; Varshney et al., 2007; González-Escalona et al. 2009; Chen et al. 2012). This study concerned to perform a rapid and simultaneous detection of seven foodborne pathogens for four different food categories including fresh food (chicken, beef meat and fish), frozen food (chicken, beef meat and filet-o-fish), processed frozen food (hotdog/sausage and chicken/beef burger), and processed preserved food (chicken/beef luncheon and pastrami) using 7-plex PCR assay.

The multiplex PCR using seven sets of primer was able to detect the total of 5-10 cfu of each pathogen. Tantawiwat et al., (2005) were able to detect 1 to $10 \mathrm{cfu}$ for E. coli, Clostridium perfringens and Klebsiella pneumonia using multiplex PCR after pre-enrichment step by culturing for $6 \mathrm{hr}$. otherwise the sensitivity was rather low to $10^{4} \mathrm{cfu} / \mathrm{ml}$. Maheux et al., (2011) were able to detect 4-5 enterococcal colony forming units using real time PCR. According to Litty et al. (2013), multiplex PCR detection limit was $10 \mathrm{cfu}$ per reaction after $10 \mathrm{~h}$ of incubation. Ojha et al. (2013) demonstrated that the sensitivity of pentaplex PCR was 120 cfu per reaction mixture of bacteria for detection of different Shigella species. Furthermore, Zheng et al., (2014) reported that simultaneous detection of five major foodborne pathogens in pork was developed by designing five pairs of primers invA gene, hlyA gene, $r f b E$ gene, nuc gene and ail gene for detecting Salmonella, Listeria. monocytogenes, E. coli O157:H7, Staphylococcus aureus and Yersinia. enterocolitica, respectively. After overnight culture, the detection limit was less than $10 \mathrm{cfu} / \mathrm{mL}$ for detection of a single pathogen and $103 \mathrm{cfu} / \mathrm{mL}$ for the simultaneous detection of the five target species. Detection of very low levels of bacterial contamination in food necessitates that these samples to be cultured for a few hours in nutrient broth for providing conditions for growth and multiplication of bacterial pathogens to a detectable level. Furthermore, dilution of inhibitory substances present in food and dilution of dead target cells, which provides some assurance that the detected DNA belongs from viable target cell. In this study, $1 \mathrm{gm}$ of the food sample was diluted in $10 \mathrm{~mL}$ nutrient broth and incubated for $2 \mathrm{~h}$ for enticement.

Comparison of bacterial occurrence frequencies in the food samples between the use of cultural traditional and advanced multiplex techniques revealed some little differences. This might be attributed to the none viability of some bacterial strains that could not able to be grown, isolated and identified classically giving positive detection results by m-PCR rather than cultural methods. In contrast, the positive detection of culture methods that gave negative when m-PCR was applied might be due to the low concentration of bacterial pathogens which could not be detected by m-PCR. 


\section{Simultaneous detection of seven foodborne Enterobacteriaceae pathogens using multiplex PCR}

The result revealed that the highest frequency percentage of the detected pathogens occurred in the processed frozen food samples (hotdog/sausages and chicken/meat burger) followed by fresh food samples. This probably due to many reasons including the low level of hygiene during the handling procedures during the transportation and/or food processing, the inadequate biosafety storage and shelf life. Therefore, the highest frequency percentage of the bacterial occurrence was recorded for Salmonella species and E. coli, which are the most common foodborne pathogens.

This study recommend the use of 7plex-PCR detection system for the rapid, accurate and unambiguous identification and detection of E. coli, Proteus sp., Enterobacter sp., Salmonella sp., Klebsiella sp., K. pneumoniae and K. oxytoca foodborne pathogens. Furthermore, this $\mathrm{m}-$ PCR assay could be used in hospitals and clinical laboratories for routine detection purposes once the method is fully evaluated on a large number of blood/fecal samples.

\section{REFERENCES}

Anbazhagan, D.; Kathirvalu, G.G.; Mansor, M.; Yan, G.O.S.; Yusof, M.Y. and Sekaran, S.D. (2010). Multiplex polymerase chain reaction (PCR) assays for the detection of Enterobacteriaceae in clinical samples. Afr. J. Microbiol. Res., 4(11):1186-1191.

Anklam, K.S.; Kanankege, K.S.; Gonzales, T.K.; Kaspar, C.W. and Döpfer, D. (2012). Rapid and reliable detection of Shiga toxin-producing Escherichia coli by real-time multiplex PCR. J. Food. Prot., 75:643-650.

Ausubel, F.M.; Brent, R. and Kingston, R.E. (1996). Current protocols in molecular biology. New York: John Wiley \& Sons.

Batt, C.A. (1997). Molecular diagnostic for diary based pathogens. J. Dairy Sci., 80:220-229.

Bean, N.H. and Griffins, P.M. (1990). Foodborne disease outbreaks in the United States, 19731987: Pathogens, Vehicles, and Trends. J. Food Microbiol., 53: 804-817.

Beili, Z.; Jinwen, X.; Shengfeng, L.; Jun, Y.; Yu, W.; Fuping, N.; Qing, Z.; Yingguo, L. and Guohua, Z. (2013). Simultaneous detection of six food-borne pathogens by multiplex PCR with a GeXP analyzer. Food Control, 32(1):198-204.

Bernner, D.J. and Farmer, J.J. (1984). Family: Enterobacteriaceae. In Bergey,s Manual of Systematic Bacteriology; vol 2 (Garrity, George; Bernner, Don J.; Krieg, Noel R. and Staley, James R. (eds.) Williams and Wilkins, Baltimore.

Bercovier, H. and Mollaret, H.H. (1984). Genus XIV. Yersinia. In N. R. Krieg (Ed.). Bergey's manual of systematic bacteriology (Vol. 1, pp. 502-506). Williams and Wilkins. Baltimore.

Brisse, S. and Verhoef, J. (2001). Phylogenetic diversity of Klebsiella pneumoniae and Klebsiella oxytoca clinical isolates revealed by randomly amplified polymer phic DNA, gyrA and parC gene sequencing and automated ribotyping. Int. J. Syst. Evol. Microbiol., 51:915-924.

Chen, J.; Tang, J.; Liu, J.; Cai, Z. and Bai, X. (2012). Development and evaluation of a multiplex PCR for simultaneous detection of five foodborne pathogens. J. Appl. Microbiol., 112:823-830.

D’Aoust, J.Y. (1989). Salmonella. In: Doyle, M.P.(ed). Food borne bacterial pathogens. Marcel Dekker, Inc., New York, Bacel, pp 327-445.

Euzéby, J.P. (1997). List of bacterial names with standing in nomenclature: a folder available on the internet. Int. J. Syst. Bacteriol., 47:590-592. 


\section{Ahmed K.A. El-Sayed et al.}

González-Escalona, N.; Hammack, T.S.; Russell, M.; Jacobson, A.P.; De Jesús, A.J.; Brown, E.. and Lampel, K.A. (2009). Detection of live Salmonella sp. cells in produce by a Taqmanbased quantitative reverse transcriptase real-time PCR targeting invA mRNA. Appl. Environ. Microbiol., 75:3714-3720.

Grant, K.A.; Kenyon, S.; Nwafor, J.; Plowman, J.; Ohai, C.; Halford-Maw, R.; Peck, M.W. and McLauchlin, J. (2008). Foodborne Pathogens and Disease. Volume 5, Number 5, $2008^{\text {a }}$ Mary Ann Liebert, Inc. DOI: 10.1089=fpd.2007.0066.

Havelaar, A.H.; Kirk, M.D.; Torgerson, P.R.; Gibb, H.J.; Hald, T. and Lake, R.J. (2015). World Health Organization Global Estimates and Regional Comparisons of the Burden of Foodborne Disease in 2010. PLoS. Med., 12(12): e1001923. doi:10.1371/ journal.pmed.1001923.

Hill, W.E. (1996). The polymerase chain reaction for the detection of food borne pathogens. Crit. Rev. Food, 36:123-173.

Hübner, I.; Steinmetz, I.; Obst, U.; Giebel, D. and Bitter-Suermann, D. (1992). Rapid determination of members of the family Enterobacteriaceae in drinking water by an immunological assay using a monoclonal antibody against enterobacterial common antigen. Appl. Environ. Microbiol., 58:3187-3191.

Jeong, S.; Gang, G.; Jong, S.; Yong, H.; Hyo, S.; Soo, B.; Young, S. and Suk, T. (2007). A Novel Multiplex PCR Assay for Rapid and Simultaneous Detection of Five Pathogenic Bacteria: Escherichia coli O157:H7, Salmonella, Staphylococcus aureus, Listeria monocytogenes, and Vibrio parahaemolyticus. J. Food Prot., 70(7): 1656-1662.

Kovtunovych, G.; Lytvynenko, T.; Negrutska, V., et al. (2003). Identification of Klebsiella oxytoca using a specific PCR assay targeting the polygalacturonase pehX gene. Res. Microbiol., 154:587-592.

Klipstein, F.A. and Engert, R.F. (1976). Purification and properties of Klebsiella pneumoniae heat-stable enterotoxin. Infect. Immun., 13:373-381.

Lantz PG, Hahnhagerdal B, Radstorm P (1994). Sample preparation methods in PCR based detection of food pathogens. Trends in Food Sc. Technol., 5:384-389.

Litty B, Prakash R, Harishchandra S, Harsh V (2013). Optimization and evaluation of a multiplex PCR for simultaneous detection of prominent foodborne pathogens of Enterobacteriaceae. Ann. Microbiol., 63:1591-1599.

Li, Y.; Zhuang, S. and Mustapha, A. (2005) Application of a multiplex PCR for the simultaneous detection of Escherichia coli O157:H7, Salmonella and Shigella in raw and ready-to-eat meat products. Meat Sci., 71:402-406.

Maheux, A.F.; Boissinot, M.; Bissonnette, L.; Bernier, J.L.; Huppe, V.; Be'rube', E.; Boudreau D.K.; Picard, F.J.; Huletsky, A. and Bergeron, M.G. (2011). Method for rapid and sensitive detection of Enterococcus sp. and Enterococcus faecalis/faeciumcells in potable water samples. Water Res., 45:2342-2354.

Malkawi, H.I. and Gharaibeh, R. (2003). Multiplex PCR for the direct detection of Salmonella enterica from chicken, lamb and beef food products. J. Basic Microbiol., 43:328-336.

Miescier, J.J.H.; Redman, D.A.; Salinger, J.A. and Lucas, J.P. (1992). Molluscan shellfish: oyster, mussels and clams. In. Vanderzant, C., Splittstoesser. (eds). Compendium of Methods for the Microbiology Examination of Goods. Washington DC, American Public Health Association, pp 897-918. 


\section{Simultaneous detection of seven foodborne Enterobacteriaceae pathogens using multiplex PCR}

Moon, G.S.; Kim, W.J. and Shin, W.S. (2004). Optimization of rapid detection of Escherichia coli O157:H7 and Listeria monocytogenes by PCR and application to field test. J. Food Prot., 67:1634-1640.

Ojha, S.S.; Yean, C.Y.; Ismail, A. and Singh, K.K.B. (2013). A pentaplex assay for the detection and differentiation of Shigella spp. Biomed. Res. International, Article ID 412370, 9 pages, doi:10.1155/2013/412370

Olsen, J.E.; Aabo, S. and Hill, W. (1995). Probes and polymerase chain reaction for detection of food borne pathogens. Int. J. Food Microbiol., 28:1-78.

Patrick, A.D.G. and Francine, G. (1984). Genus: Enterobacter and Klebsiella. In: Bergey,s Manual of Systematic Bacteriology, vol 2 (Garrity, G., Bernner, D.J., Krieg, N.R. and Staley, J.R. (eds.)) Williams and Wilkins, Baltimore.

Podschun, R. and Ullmann, U. (1998). Klebsiella spp. as nosocomial pathogens: epidemiology, taxonomy, typing methods, and pathogenicity factors. Clin. Microbiol. Rev.,11:589-603.

Radhika, M.; Majumder, S.; Murali, H.S. and Batra, H.V. (2014). A novel multiplex PCR for the simultaneous detection of Salmonella enterica and Shigella species. Brazil. J. Microbiol., 45(2): 667-676.

Radji, M.; Malik, A. and Widyasmara, A. (2010). Rapid detection of Salmonella in food and beverage samples by polymerase chain reaction. Malayasian J. Microbiol., 6:166-170.

Rahn, K.; Grandis, S.A-De; Clarke, R.C.; Mcewen, S.A.; Galan, J.E.; Ginocchio, C.; Curtiss, R. and Gyles, C.L. (1992). Amplification of an invA gene sequence of Salmonella typhimurium by polymerase chain reaction as a specific method of detection of Salmonella. Mol. Cellular Probes, 6:271-279.

Rowe, B. and Gross, R.J. (1984). Genus II Shigella. In: Krieg NR, Holt JG, editors. Bergey's Manual of Systematic Bacteriology.Vol 1. Baltimore: Williams and Wilkins. p. 423-427.

Shui-lian Bi ; Shu-ze Tang ; Xi-yang Wu and Shou-yi Chen (2013). Quantitative detection of Proteus species by real-time polymerase chain reaction using SYBR Green. Ann. Microbiol., 63:1205-1208.

Soumet, C.; Ermel, G.; Rose, N.; Drovin, P.; Salvat, G. and Colin, P. (1999). Evaluation of multiplex PCR for simultaneous identification of Salmonella spp., Salmonella enteritidis, and Salmonella typhimurium from environment swabs of poultry houses. Appl. Environ. Microbiol., 28:113-117.

Tajbakhsh, E.; Tajbakhsh, S. and Khamesipour, F. (2015). Isolation and Molecular Detection of Gram Negative Bacteria Causing Urinary Tract Infection in Patients Referred to Shahrekord Hospitals, Iran. Iran Red Crescent Med. J., 17(5): e24779.

Tantawiwat, S.; Tansuphasiri, U.; Wongwit, W.; Wongchotigul, V. and Kitayaporn, D. (2005). Development of multiplex PCR for the detection of total coliform bacteria for Escherichia coli and Clostridium perfringens in drinking water. Southeast Asian J Trop. Med. Puplic Health. 36(1):162-169.

Trafny, E.A.; Kozłowska, K. and Szpakowska, M (2006). A novel multiplex PCR assay for the detection of Salmonella enterica serovar enteritidis in human faeces. Lett. Appl. Microbiol., 43:673-679.

Varshney, B.C.; Ponnanna, N.M.; Sarkar, P.A.; Rehman, P. and Shah, J.H. (2007). Development of a monoclonal antibody-based co agglutination test to detect enterotoxigenic Escherichia coli isolated from diarrheic neonatal calves. J. Vet. Sci., 8:57-64. 


\section{Ahmed K.A. El-Sayed et al.}

Way, J.S.; Josephson, K.L.; Pillai, S.D.; Abbaszadegan, M.; Gerba, C.P. and Pepper, I.L. (1993). Specific detection of Salmonella spp. by multiplex polymerase chain reaction. Appl. Environ. Microbiol., 59:1473-1479.

Yogesh, C.; Ramakrishnan, M.A.; Naresh, J.; Kaven, H. and Sagar, M.G. (2011). Differentiation of Klebsiella pneumoniae and $K$. oxytoca by multiplex polymerase chain reaction. Intern. J. Appl. Res. Vet. Med., 9(2): 2011.

Zheng, P.; Yun, J.; Feng, G.; Lin, Z.; Guang, H. and Zheng, J. (2013). Rapid and simultaneous analysis of five foodborne pathogenic bacteria using multiplex PCR. Eur. Food Res. Technol., 237:627-637.

الكثف المتزامن لسبعة من الإنتيروبكتيريا الممرضة المصاحبة للأطعة باستخدام تفاعل البلمرة المتسلسل المتعدد

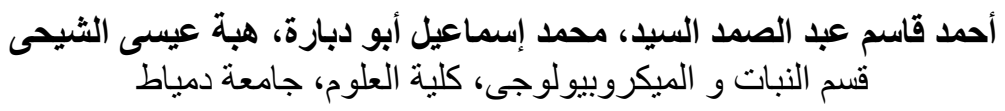

المستخلص

تعتبر أفر اد عائلة البكتبريا المعوية أحد أهم مسببات الأمر اض الرئيسية المرتبطة بالاضطر ابات المعدية المعوية

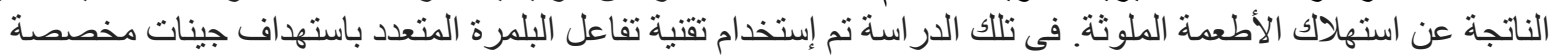

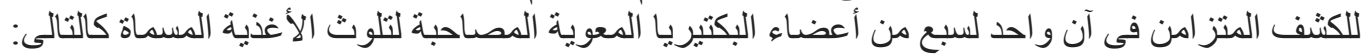

Escherichia coli (uidA), Proteus sp. (atpD), Salmonella sp. (invA), Enterobacter sp. (16S rRNA), Klebsiella sp. (gyrA), Klebsiella pneumoniae (rpoB) and K. oxytoca (pehX).

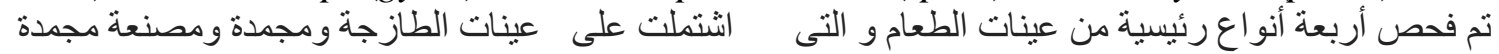

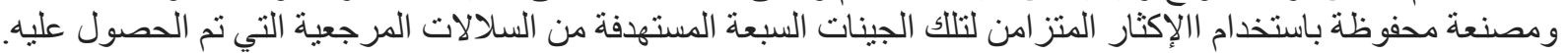

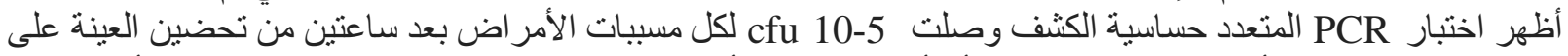

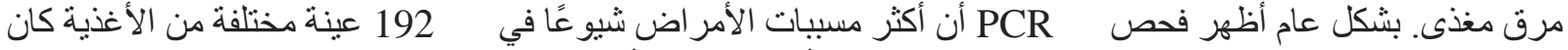

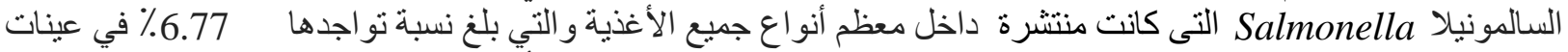

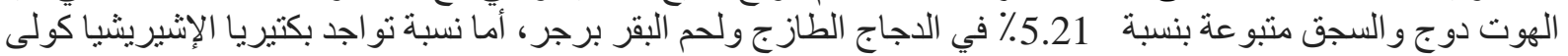
Escherichia coli

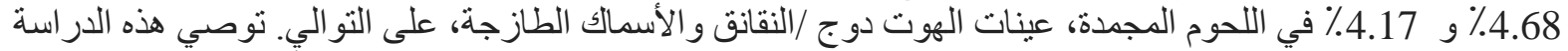

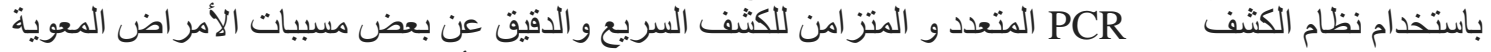
Enterobacteriaceae ، وبالتالي يمكن استخدامها للمر اقبة المنتظمة لجودة المنئ الأغذية. 